\title{
Financial Performance and Economic Impact on Capital Adequacy Ratio in Japan
}

\author{
Siti Norbaya Yahaya ${ }^{1,2}$, Nusaibah Mansor ${ }^{1,2} \&$ Kazuhiro Okazaki ${ }^{1}$ \\ ${ }^{1}$ Graduate School of Business Administration and Computer Science, Aichi Institute of Technology, Japan \\ ${ }^{2}$ Faculty of Technology Management and Technopreneurship, Universiti Teknikal Malaysia Melaka, Malaysia \\ Correspondence: Siti Norbaya Yahaya, Graduate School of Business Administration and Computer Science, \\ Aichi Institute of Technology, 247 Yachigusa, Yakusa Cho, Toyota City, Aichi Prefecture 470-0392, Japan. Tel: \\ 81-80-4224-5034. E-mail: sitinorbaya@utem.edu.my
}

Received: January 22, 2016

Accepted: February 14, 2016

Online Published: March 15, 2016

doi:10.5539/ijbm.v11n4p14

URL: http://dx.doi.org/10.5539/ijbm.v11n4p14

\begin{abstract}
Capital adequacy is a crucial factor in determining the level of risk absorption of a banking institution. This issue has been discussed widely as it is an important yardstick to gauge the complete picture of banking performance. Capital adequacy is closely related to the economic performance of related country, therefore, this study investigates the financial performance and economic impact of capital adequacy ratio on regional banks in Japan. Five variables were employed that represent economic performance - unemployment rate, inflation rate, real exchange rate, money supply and gross domestic product, while financial performance of the regional banks consisted of six variables, namely the deposit-to-asset ratio, return on assets, return on equity, total assets, total deposits and total loans. 64 regional banks were evaluated over a period of 10 years from 2005 to 2014 . Secondary data were composed of World Bank data and the individual financial statements of Japanese regional banks. The results show a various signs of relationships between variables and it was slightly different from previous study. This was supported by result tested by panel regression analysis and correlation analysis conducted in order to measure the relationship between capital adequacy and each variable. This paper among others gives a vast reference to depositor, banking institution and policy maker in not only maintaining but also need to improve the level of capital adequacy for a stable security to all parties.
\end{abstract}

Keywords: financial performance, capital adequacy ratio, economic impact, regional bank, financial risk

\section{Introduction}

Capital adequacy play a major role in banking security, and besides that, it also portrays a bank's image as a whole, potentially attracting public confidence to invest in the bank. There is a solid public relations characteristic to capital adequacy. It is commonly accepted that the readiness of capital is a perfect sign of health of a bank and a satisfactory situation to guarantee the safeguarding of certainty by investors, creditors and depositors.

Banking performance is significantly related to the macroeconomic performance, changes in level of gross domestic product (GDP) will affect level of capital adequacy ratio. Banks will conduct strict policies in lending activity since borrower's ability to repay the loan may decrease. Fall in GDP result to increase in CAR as banking institution is now securing more percentage in CAR.

The collapse of Lehman Brothers in 2008 and the Great East Japan Earthquake 2011 massively impacted the Japanese financial system. For the most part, regional banks in Fukushima Prefecture were minimally affected. Regional banks are currently required to maintain a $4 \%$ capital adequacy ratio, with some arguments put forth for whether areas tending to be affected by natural disasters need to maintain the same figure as an area with less of a probability of being hit by such a catastrophe. Affected areas probably need additional financial aid to recover from their operational risk.

Japan's economic growth is anticipated to drop slightly in 2011. Japan's gross domestic product (GDP) increased in the third quarter of 2011 since 2010, other than that progressive growth is projected in 2012. Most sectors trade statistics also indicate positive signs. In addition, the recovery of Japan's export sector was influencing by weak economic conditions in Europe and the US. 
SMEs' performances in particular area affected by Great East Earthquake in 2011 are slightly decreased due to migration and decreasing number of local population. Besides that due to the contamination and radiation problem from nuclear power plant leakage, consumer avoids production from Fukushima Prefecture. According to Junichi, Akira \& Masashi, (2013), small and medium enterprises in affected area faced with difficulties in obtaining a new loan is most likely the result of the double loan problem. This may increase the risk associated with the non-performing of the affected bank. Other than that, Japan economic performance also contributes to the performance regional banks. Therefore, this study attempts to investigate the relationship between Japan's economic performance and the financial position of regional bank with respect to capital adequacy ratios. This ratio reflects the management of credit risk and it is critical for protecting the depositor and to avoid any possibilities of bankruptcy.

\subsection{Overview of Japanese Financial System}

Japanese regional banks have earned immense loyalty from customers because of their prudent management over their long history. The regional banks are devoted to protecting their stakeholders thorough practical management based on self-responsibility by working to stimulate further restructuring and proficiency in all aspects of management. They are efficient in responding to management issues and improving their operational risk by diversification of customers' needs. The introduction of the Basel Accord requires bank to calculate CAR based on international standards. According to the Japanese Bankers Association (Zenginkyo), banks with international standards need to maintain a CAR of $8 \%$ while domestic standards simply requires CARs of $4 \%$.

There are a total of 64 regional banks in Japan operating based in the principle city of a prefecture. As a consequence, they normally have resilient relationships with local enterprises and government organisations. As of 2014, regional banks in Japan hold $¥ 172$ trillion in loans and discounted bills, possess $¥ 236$ trillion in deposits, operate 7.5 thousand branches, employ 132 thousand employees, manage 35 thousand automated teller machines and are capitalized with $¥ 2,556$ billion in stock.

\section{Literature Review}

Capital adequacy has always been seen as a vital issue for financial institutions. It is defined as the percentage ratio of a financial institution's primary capital to its assets and used as a measure of its financial strength and stability (Asikhia \& Sokefun, 2013).

Romdhane (2012) studied the determinants of banks' capital ratio in an emerging country. A model was developed to measure the relationships between a number of key variables of the banks and their profitability ratio. The study covered 18 banks with semi-annual data from 2002 to 2008 . The findings seemed to agree that the interest margin and risk strongly influenced the capital ratio. Guarantees by the bank to provide returns to investors may raise banking pressure, but is contrasted to the fact that investors value higher returns, potentially attracting more deposit to the institution.

According to Victor and Juan (2000), optimal financial decisions must consist of setting a capital ratio that is the sum of the regulatory minimum plus a capital cushion. This ratio assists in reducing the probability of capital distress below the regulatory necessity.

The Basel Standard was introduced in 1988 and implemented subsequent feedback from financial institutions. The standard was upgraded to be more risk sensitive. Although various parties argued against it, the standard is still distinctive as a safe reference associated with security risk encountered by most of the financial sector.

The Basel Standard made requirements for capital that needed to be locked by financial institutions to protect them from any hidden risk that might disrupt their operations. In Japan, Basel rules are binding to 16 internationally active banks that encompass approximately 56\% of Japanese banking sector assets. Local banks are administrated by the Financial Services Agency of Japan (JFSA) that enforces a marginally modified version of Basel 111.

The Basel committee suggested a minimum capital requirement needs to be secured at $8 \%$ of risk weighted assets (RWA), so, therefore, the explanation of capital risk management must be clearly defined by reflecting the combination of different types of risk that may affect banking operations.

According to Basel standards, the level of risk visible to the bank needs to be revealed to the central bank. The financial crisis in 2008 had attracted full attention from the financial markets, and Basel 11 was reviewed and a new standard (Basel 111) was released in 2010. Nevertheless, Basel 11 is not fully superseded by Basel 111.

The main resolution of the new rules was to encourage a solid banking system by fully focused on liquidity, leverage and capital. In the Basel III Japan Assessment, the Basel committee gave Japan rankings of "Grade 3", 
"Compliant" or "Largely Compliant" in each detailed evaluation (Toshikazu, Bingham, \& Aizawa, 2014).

The Basel committee seeks to improve capital adequacy and liquidity risk management by introducing more stringent risk assessment to strengthen capital (Aleksandra, Dalia, \& Julija, 2014). Even though the Basel standards apply to international banks, capital adequacy is thought to have a positive relationship with profitability for both international and local bank (Abba, Zachariah, \& Inyang, 2013).

Hanke (2013) found that in 2010, the Bank of International Settlements (BIS) introduced Basel III - a global regulatory framework - for the purpose of hiking capital requirements.

The primary function of bank capital is to provide resources to absorb possible future losses on assets (Ahmet \& Hasan, 2011). In determining the level of capital needing to be secured by any deposit-taking institution, macroeconomic indicators, such as inflation, economic growth and the employment rate, need to be considered as the indicators will significantly influence risk management process (Harley, 2011).

Adegbite (2010) agreed that macroeconomic stability acts as a major factor in financial steadiness, it is key for maintaining stable prices and it insures public sector deficits are marginal and external debt is sustainable. Banks with greater CARs will absorb higher levels of unpredicted losses before becoming insolvent. This study considered economic indicators and the financial positions of each bank as variables to examine the impact of the capital adequacy ratio.

Asikhia and Sokefun, (2013) indicated that capitalisation and profitability are indicators of bank risk management efficiency and mitigate losses not covered by current earnings. Profit or returns generated by the bank demonstrates the level of security, and besides-the investment from investor will be higher. Thus, profitability plays a major role in convincing depositors to supply funds in the form of bank deposits on beneficial terms.

Previous studies observed that bank profitability is normally measured by return on assets (ROA), return on equity (ROE) and net interest margins (NIM). ROA is commonly affected by a bank's policy decisions and uncontrollable factors connected to the economy and government regulations. Many regulators believe ROA is the best measure of bank profitability (Hassan \& Bashir, 2003). In addition, profitability is best represented by ROA, as it shows the ability of the firm to generate returns on its portfolio of assets.

Harley (2011) investigated the impact of banks' characteristics, financial structure and macroeconomic indicators on banks' capital bases in the Nigerian banking industry for 28 years. The study applied an error correction framework and revealed that economic indicators, like rate of inflation, real exchange rate, demand deposits, money supply, political instability and return on investment are the most robust predictors of the determinants of capital adequacy in Nigeria. Additionally, the study also determined that there is a negative relationship between inflation and banks' capital base as inflation erodes bank capital in most developing economies.

Abba et al. (2013) examined the relationship between capital adequacy and banking risk. Three independent variables were used - risk-weighted asset ratio, deposit ratio and inflation rate. Twelve banks were sampled from a population of twenty-two banks in the Nigerian banking industry over a period of five years. The study adopted value at risk theory and found that changes in the capital adequacy ratio are explained by changes in the independent variables - there is a significant negative relationship between risk and the capital adequacy ratio of banks, meaning that when risk levels rise, the capital adequacy ratio falls in the Nigerian banking industry.

According to Adegbite (2010), there is a mutual connection between stability in macroeconomic, regulatory and supervisory policies. It helps maintain the strength of a financial institution. If, however, an institution becomes unstable, then the policies should be geared towards resolution policies.

Samson and Harley (2012) examined the impact of capital adequacy in the banking sub-sector and the growth of the Nigerian economy using macroeconomic variables over a period of 30 years. It employed the error correction framework and co-integration techniques to test the relationship between bank capital base and macroeconomic variables. The study suggested that political stability might reduce financial distress and bankruptcy. In addition, the study also established that there is a negative relationship between inflation and banks' capital base as inflation erodes bank capital in most developing economies.

Ahmet and Hassan (2011) examined the determinants of Turkish banks' capital adequacy ratio and its effects on financial positions of banks for five years. The study used nine variables from different viewpoints, including profitability, leverage, liquidity and the size of the bank. It was observed that leverage had negative a relationship with while profitability positively influenced the CAR. 


\section{Methodology}

The purpose of this study was to examine the factors influencing Japan regional banks' capital adequacy ratios and its effect on financial position and economic level. Secondary data were gathered from World Bank data and the individual financial statements of 64 regional banks in Japan. This study covered a 10 years period, beginning in 2005 to 2014 .

In order to analyse the relationship between a banks' financial position, represented by total assets (TA), total loans (TLoan), total deposit (TDep), return on assets (ROA), return on equity (ROE) and the deposit-to-asset ratio (DAR) with the dependent variable, capital adequacy ratio (CAR), panel data regression methodology was used. Other than that, the same methodology was applied to investigate the relationship between economic level and CAR whereby the economic level will use the inflation rate (INF), real exchange rate (REx), unemployment rate (UNEM), money supply (MS) and gross domestic product (GDP) as economic indicators. CAR is calculated according to the formula and rules fixed by Japanese Bankers Association. A clear picture of variable can be seen in Figure 1.

Total assets (TA) represent the size of the bank. It is important to determine the extent of the ability of the firm to generate profits in future. It also helps firms operate in the long-term. Thus, total assets directly influence the calculation of CAR.

Total loans (TLoan) include short-term and long-term debt. It is also considered a company commitment and firms need to make sure they possess the ability to survive by being able to pay the debt in a fashion designated by the creditor. Risk in the form of interest rate risk and operational risk will be mitigated if the company is able to generate sufficient profits to service existing loans.

Total deposits (TDep) are known as the amount of the investor or depositor's money that is placed with the institution. Companies with high profiles are likely to gain more profits compare to companies that are highly exposed to financial risk. This indicator is really about the security of the investor associated with their deposit.

Return on assets (ROA) by definition is a ratio of net income and total assets. It shows how profitable a firm is relative to its total assets. ROA convey the message of how efficient the firm is in generating earnings.

Return on equity (ROE) indicates the ratio of net income and shareholder equity. The money invested by shareholders is projected to be used in wise investments that will generate high returns. Higher ROEs will affect the CAR of the company since the shareholders will contribute more capital to the company

The deposit-to-asset ratio (DAR) is one that measures the ratio of deposits used to generate assets of the company. DAR seems to have a positive influence on the CAR of a company.

Inflation rate (INF) by definition recorded the changes of price level of goods and services that may affect the level of consumer purchasing power. Inflation rate is a vital indicator for evaluating a country's economic level. In order to have an excellent economy, the government needs to control the prices of goods and services so as to positively regulate the cost of living for the consumer.

Real exchange rate (REx) is the purchasing power of one currency relative to another. The difference between currencies affects the stability of a particular currency. Besides that, it also affects economic level of a country. Currency levels significantly impact import and export businesses as consumer need to pay an import tariff from trading imported goods.

Unemployment rate (UNEM) is defined as the percentage of the total labour force that is unemployed but actively seeking employment and willing to work. It is the most closely observed statistic because a growing rate is a sign of a diminishing economy that may call for cuts in interest rates. In addition, a falling rate indicates a rising economy that is commonly complemented by a higher inflation rate and may necessitate an increase in interest rates.

Money supply (MS) is total amount of money available in an economy at a specific time. Standard measures normally include currency in circulation and demand deposits. Records of money supplies can be found at a country's central bank. Money supplies need to be closely monitored as it may influence the level of inflation and the exchange rate.

Gross domestic product (GDP) is the monetary value of finished goods and services produced within a country during a specific time period. GDP includes private and public consumption, investment and the difference between exports and imports. GDP is a vital statistic for measuring a country's economic level. 


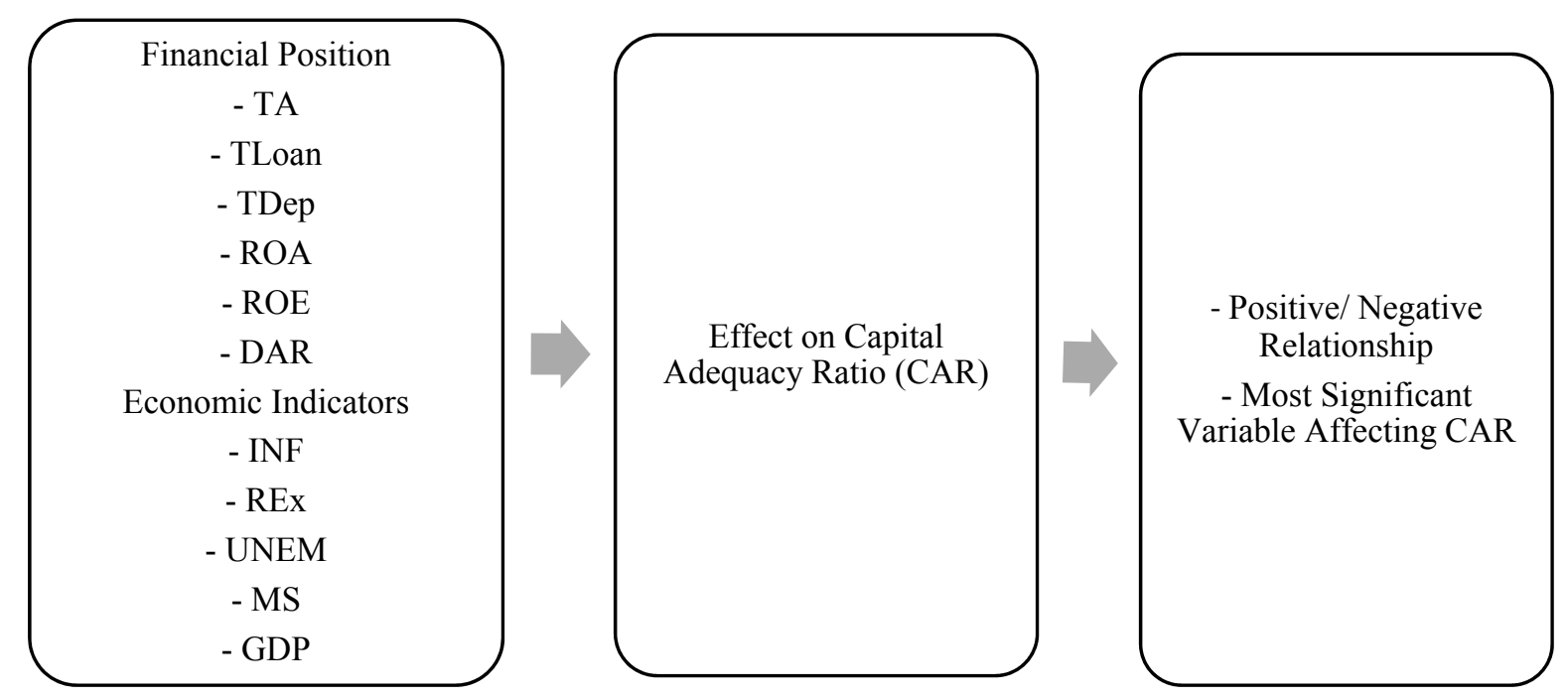

Figure 1. Research framework

\subsection{Econometric Model}

This study investigates the effects of banks' financial position and economic indicators on the capital adequacy ratio by using the panel regression model. Based on a review of the theoretical literature, the following panel regression model is formed:

$$
C A R_{i t}=\beta_{0}+\beta_{1} T A_{i t}+\beta_{2} \text { TLoan }_{i t}+\beta_{3} \text { TDep }_{i t}+\beta_{4} R O A_{i t}+\beta_{5} R O E_{i t}+\beta_{6} D A R_{i t}+\beta_{I} I N F_{i t}+\beta_{2} R E x_{i t}+\beta_{3} U N E M_{i t}+
$$

In the previous equation, $\beta_{0}$ is a constant and $\beta$ is a coefficient of the variables while $\varepsilon_{\mathrm{it}}$ is the residual error of the regression.

\section{Results and Discussion}

Table 1 shows the results of numerous descriptive analyses calculated based on selected variables, specifically the means and standard deviation. Dependent variable is represent by capital adequacy ratio (CAR) while others are independent variables. During the study period, CAR averages at $10.94 \%$, this figure being rather high compared to the regulatory requirement of $4 \%$. This indicates that regional banks remained strong and stable over the course of the study. Furthermore, the standard deviation of CAR is 3.52\%, demonstrating the slight disparity between the CAR of various banks.

Table 1. Descriptive analysis of study variables

\begin{tabular}{llll}
\hline Variables & Observation & Mean & Std. Dev \\
\hline CAR & 640 & 10.941 & 3.529 \\
TA & 640 & 37236.51 & 26341.26 \\
TLoan & 640 & 25341.14 & 30301.92 \\
TDep & 640 & 35686.15 & 22365.04 \\
ROE & 640 & 3.6222 & 13.193 \\
ROA & 640 & 0.864 & 6.115 \\
DAR & 640 & 88.698 & 45.649 \\
INF & 640 & -0.05 & 0.672 \\
REx & 640 & 83.95 & 29.159 \\
UNEM & 640 & 4.397 & 0.386 \\
MS & 640 & 1.47 & 1.283 \\
GDP & 640 & 0.87 & 2.590 \\
\hline
\end{tabular}

Table 2 is the correlation matrix employed to determine the relationship between dependent and independent variables. This study used regression analysis in order to check the effect and relationship of each variable, the same model used in previous study done by Harley (2011). It can be observed that there are inverse relationships 
between INF, REx, GDP and CAR, while other variables show positive relationship. There are negative relationship between inflation and CAR, this is expected sign as shown by previous study, Japan government need to retain low level of inflation in order to be further globally competitive.

Table 2. The pairwise correlation matrix for dependent (CAR) and explanatory variables

\begin{tabular}{|c|c|c|c|c|c|c|c|c|c|c|c|c|}
\hline & CAR & TA & TWen & Thean & ROA & ROE & DAR & INF & REx & UNEM & MS & GDP \\
\hline CAR & 1.000 & & & & & & & & & & & \\
\hline \multirow[t]{2}{*}{ TA } & 0.321 & 1.000 & & & & & & & & & & \\
\hline & $\cdots$ & & & & & & & & & & & \\
\hline \multirow[t]{2}{*}{ TDep } & 0.301 & 0.981 & 1.000 & & & & & & & & & \\
\hline & $\cdots$ & $\cdots$ & & & & & & & & & & \\
\hline \multirow[t]{2}{*}{ Thoan } & 0.136 & 0.579 & 0.592 & 1.000 & & & & & & & & \\
\hline & $\cdots$ & $\cdots$ & $\cdots$ & & & & & & & & & \\
\hline \multirow[t]{2}{*}{ ROA } & 0.034 & 0.148 & 0.158 & 0.078 & 1.000 & & & & & & & \\
\hline & & $\cdots$ & $\cdots$ & $*$ & & & & & & & & \\
\hline \multirow[t]{2}{*}{ ROE } & 0.093 & 0.117 & 0.140 & 0.088 & 0.049 & 1.000 & & & & & & \\
\hline & $*$ & $\cdots$ & $\cdots$ & $*$ & & & & & & & & \\
\hline \multirow[t]{2}{*}{ DAR } & 0.149 & -0.028 & 0.104 & 0.075 & 0.006 & 0.067 & 1.000 & & & & & \\
\hline & $\cdots$ & & $\cdots$ & & & & & & & & & \\
\hline \multirow[t]{2}{*}{ INF } & -0.093 & -0.078 & -0.083 & -0.081 & 0.019 & -0.149 & -0.031 & 1.000 & & & & \\
\hline & $*$ & $*$ & $*$ & $*$ & & & & & & & & \\
\hline \multirow[t]{2}{*}{ REx } & -0.064 & -0.083 & -0.084 & -0.008 & -0.003 & 0.007 & 0.038 & 0.175 & 1.000 & & & \\
\hline & & $*$ & 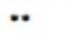 & & & & & $\cdots$ & & & & \\
\hline \multirow[t]{2}{*}{ UNEM } & 0.079 & 0.092 & 0.105 & 0.099 & -0.003 & 0.098 & 0.049 & -0.797 & -0.313 & 1.000 & & \\
\hline & *. & $*$ & $\cdots$ & $*$ & & & & $\cdots$ & $\cdots$ & & & \\
\hline \multirow[t]{2}{*}{ MS } & 0.119 & 0.158 & 0.169 & 0.079 & -0.029 & 0.055 & 0.004 & -0.232 & -0.123 & 0.195 & 1.000 & \\
\hline & & $\cdots$ & $*$ & $*$ & & & & $\cdots$ & $\cdots$ & $\cdots$ & & \\
\hline \multirow[t]{2}{*}{ GDP } & -0.049 & -0.015 & -0.017 & -0.072 & -0.016 & 0.034 & -0.036 & 0.222 & -0.529 & -0.175 & -0.145 & 1.000 \\
\hline & & & & & & & & $\cdots$ & $\cdots$ & $\cdots$ & $\cdots$ & \\
\hline
\end{tabular}

Note. $(* * *)$ and $(* *)$ significant at $1 \%$ and $5 \%$ respectively.

Furthermore, all variables were tested for multicollinearity through using variance inflation factors; the results elicited being fairly satisfactory. Multicollinearity measure how much the variance of the coefficients (square of standard deviation) is increase because of collinearity (Romdhane, 2012). The regression results will be analysed using a fixed effect model as detailed in Table 3. Adjusted R square values are $13.2 \%$, suggesting that $13.2 \%$ variability of the CAR can be explained by TA, TDep, TLoan, ROA, ROE, DAR, INF, REx, UNEM, MS and GDP, while the other $86.8 \%$ would be explained with other variables.

Financial position represent by TLoan shows a negative relationship with CAR and is significant at $1 \%$. This indicate the wrong sign as a positive sign is normally expected and in line with previous study, as the high risk of exposure by the bank through loan release requires bank to keep high reserves to mitigate default risk. TDep is significant at $1 \%$ with inverse relationship with CAR, the more deposit reserve will give more security to the bank, in this case bank have an option for other banking activity instead of locking more percentage of CAR. ROE indicates positive relationship and significant at 5\%. Other than that, DAR indicate a positive relationship, this is in line with result produced by Al-Sabbagh (2004).

Economic performance represented by GDP and MS show a negative sign, implying worsening economic levels should encourage the banks to attract more reserve to avoid bankruptcy. Changes in $1 \%$ level of money supply leads to an increase in CAR. This result is in line with finding from previous study Harley (2011). Real exchange rate (REx) displays inverse relation with CAR, this sign similar with the previous study Samson et al (2012), increase in REx will reduce the flow of trade activity and lowering the level of foreign direct investment (FDI).

TA, TDep, TLoan and DAR are significant at $1 \%$ while ROE, INF, and UNEM are significant at $5 \%$. 
Table 3. Panel regression results

\begin{tabular}{ll}
\hline Explanatory Variables & Fixed Effect Regression Model \\
\hline Constant & 10.05865 \\
TA & 0.0001232 \\
TDep & -0.0000241 \\
TLoan & -2.91000 \\
ROA & -0.00593 \\
ROE & 0.03825 \\
DAR & 0.01432 \\
INF & -0.25281 \\
REx & -0.00899 \\
UNEM & -0.75243 \\
MS & -0.06837 \\
GDP & -0.11667 \\
N x T $=64 \times 10$ & 640 (strongly balanced) \\
R $^{2}$ & 0.1320 \\
\hline
\end{tabular}

\section{Conclusion and Future Research}

This study sought to investigate the relationship between financial performance of Japanese regional banks and the economic performance of Japan with the capital adequacy ratio. Secondary data is used and gathered from annual report of regional bank in Japan and economic statistic is taken from World Bank report. This study covered 10 years period from 2005 to 2014 with a total number of 640 observations. Five variables were employed to represent the economic performance while 6 variables represent financial performance of the regional bank.

Regression analysis shows a various signs of relationships between variables were slightly different from previous study, like for instance the fact that inflation should be positively associated, through in this study, inflation and CAR are inverse to one another. It can be concluded that other factors will have more impact on regional banks when determining their CARs.

This study faced difficulties in searching for some literature about the Japanese banking performance due to most of the references are published in Japanese language, therefore this study is hope to furnish optional reference for non Japanese speaker.

In future research, additional variables should be tested in order to get more comprehensive results to explain the CAR. This research is expected to give more references to researcher especially in studying Japan banking performance and also in analysing Japan economic performance. Besides that it give a compelling evidence to investor and banking institution about the importance of securing enough capital in order to mitigate the banking risk.

\section{Acknowledgments}

I would like to express my gratitude to Aichi Institute of Technology, Ministry of Education, Malaysia, and the Universiti Teknikal Malaysia Melaka for sponsorship of my Doctoral studies.

\section{References}

Abba, G. O., Zachariah, P., \& Inyang, E. E. (2013). Capital Adequacy Ratio and Banking Risks in the Nigeria Money Deposit Banks. Research Journal of Finance and Accounting, 4(17).

Adegbite, E. O. (2010). The Nigerian Financial System: Emerging Issues and Global Relevence. Department of Finance University of Lagos.

Ahmet, \& Hasan. (2011). Determinant of capital adequacy ratio in Turkish Bank: A panel data analysis. African Journal of Business Management, 5(27), 11199-11209. http://dx.doi.org/105897/AJBM 111957

Aleksandra, Z. B., Dalia, V., \& Julija, S. V. (2014). Capital Adequacy (Solvency) and Liquidity Risk Management: Analysis, Evaluation, and Possibilities for Improvement. University Lithuania.

Al-Sabgah, N. M. (2004). Determinants of Capital Adequacy Ratio in Jordian Banks. MSc Thesis, Yarmouk University of Jordan.

Asikhia, O., \& Sokefun, A. (2013). Capital Adequacy and Banks' Profitability: Empirical Evidence from Nigeria. 
American International Journal of Contemporary Research, 3(10).

Basel Committee on Banking Supervision. (2001). Overview of the New Capital Accord.

Hanke, S. H. (2013). Basel's Capital Curse. Financial Nigeria: Development and Finance Journal, 5(54), 34-37.

Harley, T. W. (2011). Determinant of Capital Adequacy in the Banking Sub sector of the Nigerian Economy: Efficacy of Camels (A Model Specification with Co Integration Analysis). International Journal of Academic Research in Business and Social Sciences, 1(3).

Hassan, M. K., \& Bashir, A. H. M. (2003). Determinants of Islamic banking profitability. In the 10th ERF Annual Conference. Morocco.

Japanese Bankers Association. (n. d.). Retrieved from http://www.zenginkyo.or.jp/en/outline/list-of-members/

Junichi, A., Akira, S., \& Masashi, Y. (2013). Still Rooms to Devise for Loan to Disaster- Affected Firm. Japan Financial Report, FY2012. Japan Center for Economic Research.

Regional Bank Association of Japan. (n. d.). Retrieved from http://www.chiginkyo.or.jp/app/contents.php?category_id=17

Romdhane, M. (2012). The Determinants of Banks' Capital Ratio in Developing Countries: Empirical Evidence from Tunisia. Research Journal of Finance and Accounting, 3(1).

Samson, O. (2012). Department of Finance University of Lagos, Lagos, Nigeria. In T. W. Harley (Ed.), An Empirical Analysis of Capital Adequacy in the Banking Sub-Sector of the Nigeria Economy. http://dx.doi.org/10.5539/ijef.v4n5p208

Toshikazu, S., Bingham, S., \& Mimura, A. (2014). The Implementation of the BASEL III guidelines in Japan Banking. Finance and Capital Markets Law Commission.

Víctor, E. B., \& Juan, M. B. (2000). The Effectiveness of Bank Capital Adequacy Requirements: A Theoretical and Empirical.

\section{Copyrights}

Copyright for this article is retained by the author(s), with first publication rights granted to the journal.

This is an open-access article distributed under the terms and conditions of the Creative Commons Attribution license (http://creativecommons.org/licenses/by/3.0/). 